\title{
The effect of dietary magnesium oxide supplementation on fatty acid composition, antioxidative capacity and meat quality of heterozygous and normal malignant hyperthermia (MH) pigs
}

\begin{abstract}
The objective of this research was to examine the impact of supplementation with magnesium oxide (MgO) on the fatty acid composition, antioxidative capacity and quality parameters, determined on 24 pork longissimus muscles (LD). Crossbred pigs equal for halothane genotypes (12 normal, nonmutant - NON, 12 heterozygous, monomutant - MON) and sex, were fed a diet supplemented with MgO (3.6 g magnesium daily) for 5 days prior to the slaughter. There was a tendency of higher intramuscular fat, a significant higher concentration of C17:0 and C18:2n-6, C22:5n-3 and the total amount of n-3 fatty acids $(P<0.05)$ in LD of supplemented pigs. A higher resistance to in vitro stimulation of peroxidation in muscle with $\mathrm{MgO}$ supplementation was observed. Increasing dietary level of $\mathrm{MgO}$ resulted in higher concentration $(\mathrm{P}<0.05)$ of magnesium in plasma. Genotype had significant effects on some quality indicators . Pigs fed the MgO supplemented diet had higher muscle $\mathrm{pH}$ compared to pigs fed the control diet. Significant differences $(\mathrm{P}<0.05)$ were received between control heterozygous pigs and MgO normal pigs. The LD of pigs fed diets supplemented with MgO had lower percentage of drip loss compared to pigs fed the control diet. Significant differences $(\mathrm{P}<0.05)$ were found between heterozygotes control group and the other three groups. In conclusion MgO supplementation could not only improve post mortem $\mathrm{pH}$ rate breakdown and water holding capacity but also the antioxidant stability.
\end{abstract}

Key Words: pig, MH status, muscle, magnesium, fatty acid, antioxidant capacity, meat quality

\section{Zusammenfassung}

Titel der Arbeit: Auswirkungen einer Zufütterung von Magnesiumoxyd auf die Fettsäurezusammensetzung, die antioxidative Kapazität und die Fleischqualität bei Schweinen mit unterschiedlichem MH-Status Der Einfluss einer Zufütterung von Magnesiumoxid auf die Fettsäurezusammensetzung, die antioxidative Kapazität und die Fleischbeschaffenheit bei Schweinen wurde untersucht. Kreuzungstiere (n=24), gleichverteilt nach Gechlecht und Halothangenotyp (12 normal, NON, 12 heterozygot, MON) wurden entweder mit Kontrollfutter oder mit Kontrollfutter, ergänzt durch MgO (3,6 g täglich) 5 Tage vor dem Schlachten gefüttert. Der intramuskuläre Fettgehalt war in der Tendenz erhöht, die Konzentration der C17:0, C18:2n-6, C22:5n-3 und die Summe der n-3 Fettsäuren waren signifikant $(\mathrm{P}<0,05)$ höher im Schweinemuskel bei MgO Ergänzung. Im Muskel dieser Tiere wurde auch eine erhöhte antioxidative Kapazität gegenüber einer stimulierten Oxidation festgestellt. Der Genotyp hatte einen signifikanten Einfluss auf einige Fleischbeschaffenheitsmerkmale. Die MgO Supplementierung führte zu eienem erhöhten $\mathrm{pH}$ Wert gegenüber den durch Kontrollfütterung erhaltenen. Signifikante Differenzen $(\mathrm{P}<0,05)$ ergaben sich zwischen den heterozygoten Kontrolltieren und den normalen MgO Tieren. Die MgO Supplementierung führte auch zu einem geringeren Dripverlust gegenüber der Kontrollgruppe. Die Differenzen zwischen der heterozygoten Kontrollgruppe und den anderen drei Gruppen war signifikant. Eine Futtergänzung mit MgO kann nicht nur den $\mathrm{pH}$ Wert günstiger gestalten, sondern auch die Wasserhaltekapazität erhöhen sowie eine erhöhte antioxidative Kapazität herbeiführen.

Schlüsselwörter: Schwein, MH Status, Muskel, Magnesium, Fettsäuren, antioxidative Kapazität, Fleischqualität

\section{Introduction}

Numerous nutritional and processing treatments have been evaluated for their effectiveness to improve pork quality. Pig finishing diets supplemented with vitamins 
(specifically vitamin E) and minerals helped to improve meat quality (RAMSEY et al., 1995). Research have been shown that Mg-supplementation may have beneficial effects on the behavior (KUHN et al., 1981), stress response (LUDVIGSEN, 1985; KIETZMANN and JABLONSKI, 1985; D'SOUZA et al., 1998), skeletal muscle metabolism, and meat quality (SCHAEFER et al., 1993; D'SOUZA et al., 1999; LAHUCKY et al., 2004; BAHELKA et al., 2004) of swine. It has been reported that the inclusion of $\mathrm{Mg}$ in finishing diets reduces plasma cortisol and catecholamine concentrations during transportation (KIETZMANN and JABLONSKI, 1985) and influences positively the $\mathrm{Mg}^{2+}$ inhibition of $\mathrm{Ca}^{2+}$ release in muscle of $\mathrm{MH}$ pigs as an important factor in the development of the MH syndrome (OWEN et al., 1997; LAHUCKY et al., 2004). However, there are also contradictory results concerning the improvement in pork quality (KUHN et al., 1982; LUDVIGSEN, 1985; OTTEN et al., 1992; SCHAEFER et al., 1993; D'SOUZA et al., 1998; APPLE et al., 2001; LAHUCKY et al., 2004; BAHELKA et al., 2004). Long-term supplementation of swine diets with magnesium fumarate resulted in higher muscle $\mathrm{pH}$ values and less pale, more desirable-coloured pork (OTTEN et al., 1992), but supplementing diets of finishing pigs with magnesium aspartate for only 5 days prior to slaughter also reduced drip loss, improved pork colour, and reduced the incidence of pale, soft, exudate pork (SCHAEFER et al., 1993; D'SOUZA et al., 1998). Positive effects on muscle metabolism and on meat quality with supplementation magnesium oxide were recently received using MH pigs (LAHUCKY et al., 2004; BAHELKA et al., 2004). Supplementing the diets of growing-finishing pigs with MM (Magnesium mica, silicate product containing $8 \% \mathrm{Mg}$ ) reduced the number of carcasses with a pale pinkish-grey colour and increased the number of carcasses with pink to purplish-red colour (WATSON et al., 1999), but residual effects of Mg-supplementation (MM) on pork quality during refrigerated stored were also studied (APPLE et al., 2001) and the data indicated inclusion of $\mathrm{MM}$ in swine diets may retard the onset of oxidative rancidity in vacuum-packaged pork loins.

The objective of this study was to investigate the additional effects of supplementing diets of growing-finishing heterozygote and normal $\mathrm{MH}$ pigs with magnesium oxide on fatty acids composition, antioxidant stability and meat quality attributes.

\section{Material and Methods}

Animals and diets

A total of 24 pigs were used in the study. Pigs were the progeny of crossbred sires (Pietrain $\mathrm{x}$ Hampshire tested by DNA probe as heterozygote on $\mathrm{MH}$ ) mated to dams (Large White $\mathrm{x}$ White Meaty tested as homozygote negative on $\mathrm{MH}$ ). Barrows and gilts were balanced and tested by DNA probe (FUJII et al., 1991). Equal numbers of heterozygotes $(\mathrm{n}=12)$ and normal on $\mathrm{MH}(\mathrm{n}=12)$ pigs were used in the experiment. At $80 \pm 5 \mathrm{~kg}$ live weight heterozygote pigs were biopsied (using biopsy instrument, BIOTECH, Slovakia) tested on meat quality prediction ( $\mathrm{pH}$ from bioptate after 1 hour incubation at $39^{\circ} \mathrm{C}$ ) as was described earlier (LAHUCKY et al., 2001). No significant differences in $\mathrm{pH}$ bioptate values $(6.14 \pm 0.11$ vs. $6.12 \pm 0.10)$ were found in heterozygotes between control $(n=6)$ and $M g$ supplemented pigs $(n=6)$. Pigs were divided into two groups consisting of 12 pigs each (6 heterozygotes, monomutant MON and 6 normal, nonmutant - NON on MH gene). Animals were housed in the 
control station of RIAP Nitra and penned in pairs. They were fed with commercial feed mixture (Table 1 and 2) ad libitum and had free access to water via a nipple drinker. Pigs in the control diet were fed $3 \mathrm{~kg}$ of finisher feed per pig per day for 5 days prior to the slaughter. Pigs in Mg-diet group were fed $3 \mathrm{~kg}$ of the same feed supplemented with magnesium oxide (provided by BIOFACTORY, Slovakia) at a level of $3.6 \mathrm{~g}$ additional magnesium per pig per day for 5 days prior to the slaughter.

Table 1

Formulation and nutritive value of finisher diet (Futtermittelanteile und Inhaltsstoffe in \%)

\begin{tabular}{lclr}
\hline Ingredients & $\%$ & Ingredients & $\%$ \\
\hline Barley & 42.7 & Dry matter & 86.30 \\
Wheat & 21.0 & Crude protein & 16.84 \\
Oat & 15.0 & Crude fat & 2.43 \\
Soybean meal & 12.0 & Crude fibre & 4.86 \\
Wheat brans & 2.0 & N-free extract & 41.68 \\
Meat and bone meal & 2.0 & Metabolizable energy & 12.31 \\
& & (MJ) & \\
Fodder yeast & 1.7 & Lysine & 0.86 \\
Mineral supplement & 2.5 & Calcium & 0.96 \\
Biofactor supplement & 0.6 & Phosphorus & 0.71 \\
Fodder salt & 0.5 & Magnesium & 0.22 \\
\hline
\end{tabular}

Table 2

Fatty acid composition of the basal diet (g/100 g FAME) (Fettsäurezusammensetzung des Grundfutters)

\begin{tabular}{lc}
\hline (\%) & basal diet \\
\hline C14:0 & 0.21 \\
C16:0 & 13.39 \\
C18:0 & 2.07 \\
C18:1c9 & 30.94 \\
C18:2c & 43.49 \\
C18:3n3 & 5.32 \\
$\mathrm{n}-6 / \mathrm{n}-3$ & 7.82 \\
\hline
\end{tabular}

Slaughter and sample collection

Pigs were fasted for $20 \mathrm{~h}$ with access to water, transported (about $200 \mathrm{~m}$ ) to the slaughterhouse of the institute in spring at a temperature ranging from 7 to $22^{0} \mathrm{C}$. The animals were killed at $105( \pm 5) \mathrm{kg}$ live weight by electro stunning (90-100 V, 0.9-1.0 Amps, $50 \mathrm{~Hz}$, application time 5-7 s). The animals were exsanguinated and scalded $\left(10 \mathrm{~min}, 62^{0} \mathrm{C}\right)$. Evisceration was completed about $20 \mathrm{~min}$ post mortem. Chilling of the carcasses (air temperature 2 to $4^{\circ} \mathrm{C}$, air velocity $0.5-1.0 \mathrm{~m} / \mathrm{s}$ ) started approximately at 70 min post mortem and continued overnight.

Blood samples $(4 \mathrm{ml})$ were collected at the time of exsanguination in blood collection tubes to determine calcium and magnesium concentrations. Approximately $20 \mathrm{~g}$ muscle was collected from (LD) between the $13^{\text {th }}$ and $14^{\text {th }}$ rib at 30 min post mortem. Muscle samples were frozen (liquid nitrogen) and stored at $-70^{\circ} \mathrm{C}$ before analysing for fatty acid composition and antioxidative capacity.

Sample analysis

Fatty acid composition of muscle (control, $\mathrm{n}=12$ and Mg supplemented, $\mathrm{n}=11$ ) was determined by capillary gas chromatography (NÜRNBERG et al., 1998). As an internal standard nonadecanoic acid methyl ester was used. Lipid extraction was done with chloroform/methanol $(2: 1 \mathrm{v} / \mathrm{v})$. After $18 \mathrm{~h}$ at $5{ }^{\circ} \mathrm{C}$, extracts were filtered, washed 
with $0.02 \% \mathrm{CaCl}_{2}$ in water, dried with $\mathrm{Na}_{2} \mathrm{SO}_{4}$ and $\mathrm{CaCO}_{3}(10: 1$, wt/wt) and filtered again. The fatty acid composition was analysed by gas chromatography after preparing methyl esters. Methyl esters were prepared via saponification with $0.5 \mathrm{~N}$ methanolic $\mathrm{NaOH}$ (5 minutes at $60{ }^{\circ} \mathrm{C}$ ) and subsequent methylation with boron trifluoride/methanol $\left(14 \%\right.$, wt/vol) at $60^{\circ} \mathrm{C}$ for 5 minutes. The fatty acid composition was then analysed with a Perkin Elmer gas chromatograph (PERKIN ELMER, Überlingen Germany) with a flame ionisation detector, on a $0.25 \mu \mathrm{m}$ DB 23 fused silica capillary column (J\&W SCIENTIFIC, Fisons, $60 \mathrm{~m} \mathrm{x} 0.25 \mathrm{~mm}$ i.d.).

The sum of $n-3$ fatty acids was calculated using the equation:

C18:3 n-3 + C18:4 n-3 + C20:5 n-3 (EPA) + C22:5 n-3 (DPA) + C22:6 n-3 (DHA).

The sum of $\mathrm{n}-6$ fatty acids was calculated using the equation:

C18:2 n-6 + C20:4 n-6 + C20:3 n-6 + C22:4 n-6.

The sum of the saturated fatty acids was calculated using the equation:

$\mathrm{C} 14: 0+\mathrm{C} 16: 0+\mathrm{C} 17: 0+\mathrm{C} 18: 0+\mathrm{C} 20: 0$.

For evaluating the stability of the skeletal muscle lipids (antioxidative capacity, peroxidative stability) against stimulated lipid peroxidation, a determination of thiobarbituric acid reactive substances (TBARS) was performed (BUEGE and AUST, 1978). To stimulate lipid peroxidation, $3 \mathrm{ml}$ of muscle homogenates were incubated in $0.1 \mathrm{mM}$ ascorbate and $5 \mu \mathrm{M} \mathrm{FeSO}$ for different time intervals. Volumes of $0.5 \mathrm{ml}$ were withdrawn and pipetted into $0.25 \mathrm{ml}$ of $20 \%$ trichloroacetic acid (TCA) in 100 $\mathrm{mM} \mathrm{KCl}$ at $0,30,60$, and 120 minutes incubation time. These samples were centrifuged at $10,000 \mathrm{x}$ g for $10 \mathrm{~min}$ and $0.5 \mathrm{ml}$ of the supernatants were mixed with $0.5 \mathrm{ml}$ thiobarbituric acid $(0.67 \%)$ and boiled for $15 \mathrm{~min}$ in a waterbath. The absorbance at $535 \mathrm{~nm}$ was determined immediately after cooling. At $45 \mathrm{~min}$ after slaughter the $\mathrm{pH}$ (portable $\mathrm{pH}$ meter, model 3071, JENWAY, England) was determined in the longissimus muscle $\left(13^{\text {th }} / 14^{\text {th }} \mathrm{rib}\right)$ using a combined glass electrode (P19/BNC). The day after slaughter (24 h) conductivity (TECPRO GmbH, Germany), colour (CIE LAB, MINISCAN, Lightness) and drip loss (HONIKEL, 1998) were also measured. Analysis of intramuscular fat was done by INFRATEC (Germany).

Statistical analysis

All data were analysed by the least-squares method using the GLM procedures (SAS). All tables contain the least squares means (LSM) and the standard error (SEM) of the LSM. All statistical tests of LSMs were performed for a significance level $\mathrm{p}=0.05$.

\section{Results}

The quantitatively intamuscular fat and fatty acid composition of muscle are shown in Table 3. No significant $(\mathrm{P}>0.05)$ differences were observed among genotypes for total intramuscular fat and fatty acid composition, therefore the factor genotype was not included in the variance analysis. There was only a tendency to higher levels of intramuscular fat in pigs supplemented with magnesium.

In tendency the muscle of Mg supplemented pigs had the highest intramuscular fat content and the highest concentration of all saturated fatty acids. The increase of C17:0 was significant $(\mathrm{P}<0.05)$. The polyunsaturated fatty acids content of C18:2n-6, C18:3n-3 and C22:5n-3 were higher ( $\mathrm{P}>0.05)$ in $\mathrm{Mg}$ supplemented pigs. 
Table 3

Fatty acid composition (mg/100 g muscle) of longissimus muscle in pigs (Fettsäurezusammensetzung (mg/100 g Muskel) des $m$. longissimus dorsi der Schweine)

\begin{tabular}{lrrrr}
\hline Trait & \multicolumn{2}{c}{ Control $(\mathrm{n}=12)$} & \multicolumn{2}{c}{ MgO (n=11) } \\
& LSM & SEM & LSM & SEM \\
\hline Intramuscular fat (\%) & 1.39 & 0.2 & 1.76 & 0.2 \\
C12:0 & 0.46 & 0.2 & 0.65 & 0.2 \\
C14:0 & 16.29 & 3.3 & 23.84 & 3.4 \\
C16:0 & 330.83 & 59.5 & 475.76 & 62.4 \\
C16:1 & 50.77 & 7.3 & 62.09 & 7.7 \\
C17:0 & $1.64^{\mathrm{a}}$ & 0.3 & $2.77^{\mathrm{b}}$ & 0.3 \\
C17:1 & 1.66 & 0.3 & 2.64 & 0.4 \\
C18:0 & 154.93 & 33.2 & 243.96 & 34.8 \\
C18:1trans-11 & 1.20 & 0.4 & 2.07 & 0.4 \\
C18:1cis-9 & 563.67 & 109.5 & 799.33 & 114.8 \\
C18:2n-6 & $155.76^{\mathrm{a}}$ & 8.5 & $181.22^{\mathrm{b}}$ & 8.9 \\
C18:3n-3 & $5.61^{\mathrm{a}}$ & 0.8 & $8.61^{\mathrm{b}}$ & 0.8 \\
C20:3n-6 & 8.17 & 0.5 & 8.54 & 0.5 \\
C20:4n-6 & 75.75 & 3.2 & 75.85 & 3.3 \\
C20:5n-3 & 3.52 & 0.3 & 3.60 & 0.3 \\
C22:5n-3 & $10.77^{\mathrm{a}}$ & 0.3 & $11.53^{\mathrm{b}}$ & 0.4 \\
C22:6n-3 & 3.36 & 0.3 & 3.22 & 0.3 \\
SFA & 505.62 & 96.5 & 749.76 & 101.2 \\
UFA & 949.10 & 137.8 & 1250.00 & 144.5 \\
PUFA & 263.76 & 11.6 & 293.34 & 12.1 \\
Sum of n-3 FAs & $23.26^{\mathrm{a}}$ & 1.2 & $26.96^{\mathrm{b}}$ & 1.2 \\
Sum of n-6 FAs & 239.67 & 10.7 & 265.61 & 11.2 \\
n-6/n-3 ratio & 10.40 & 0.4 & 9.99 & 0.4 \\
UFA/SFA & 1.90 & 0.05 & 1.76 & 0.05 \\
UFA/PUFA & 0.58 & 0.05 & 0.47 & 0.05 \\
\hline
\end{tabular}

a, b - P $<0.05$

No differences in fatty acid composition between heterozygote and homozygote genotypes as well as between control and $\mathrm{Mg}$ supplemented pig were observed. Nevertheless, there was an increase in antioxidative capacity in muscle of $\mathrm{MgO}$ supplemented pigs compared to control pigs (Table 4).

Table 4

The effect of dietary magnesium oxide (MgO) supplementation on TBARS values by stimulation for up to 120 min with $\mathrm{Fe}^{2+}$ /ascorbate muscle homogenates (Einfluss der Futtersupplementierung mit Magnesiumoxyd auf die TBARS-Werte von Muskelhomogenaten nach einer Stimulation der Peroxidation bis zu 120 min durch Fe2+/Ascorbat)

\begin{tabular}{llllc}
\hline Time & & Control & MgO & Significance P \\
\hline $0 \mathrm{~min}$ & Mean & 0.154 & 0.132 & $*$ \\
& S.E. & 0.006 & 0.006 & $*$ \\
& Mean & 0.622 & 0.458 & $*$ \\
& S.E. & 0.050 & 0.052 & $*$ \\
& Mean & 1.048 & 0.800 & - \\
& S.E. & 0.067 & 1.358 & 0.070 \\
\end{tabular}

$* \mathrm{P}<0.05$

Plasma calcium and magnesium concentrations are presented in Table 5. Plasma magnesium concentrations were higher $(\mathrm{P}<0.05)$ in pigs fed the $\mathrm{MgO}$ supplemented diet then in pigs fed the control.

Muscle $\mathrm{pH}$ and meat quality results are shown in Table 6. Pigs that were fed the MgO supplemented diet had higher muscle $\mathrm{pH}$ compared with pigs fed the control diet. 
Significant differences $(\mathrm{P}<0.05)$ we received between control heterozygous pigs and MgO normal pigs.

Table 5

Least squares means for the effects of diet (D) and genotype (G) on plasma calcium and magnesium concentration at slaughter (Einfluss des Futters (D) und des Genotyps (G) auf die Konzentration von Calcium und Magnesium im Plasma des Schlachtblutes)

\begin{tabular}{|c|c|c|c|c|c|c|c|}
\hline \multirow[t]{2}{*}{ Item } & & \multicolumn{2}{|c|}{ Control } & \multicolumn{2}{|c|}{$\mathrm{MgO}$} & \multirow[t]{2}{*}{$\overline{S E}$} & \multirow{2}{*}{$\begin{array}{c}\text { Interaction } \\
\text { Gx D }\end{array}$} \\
\hline & & MON & NON & MON & NON & & \\
\hline Calcium, mg/l & $\overline{L S M}$ & 25.10 & 24.90 & 24.50 & 24.70 & 0.48 & - \\
\hline Magnesium, mg/l & LSM & 8.43 & 8.63 & 9.60 & 9.25 & 0.42 & - \\
\hline
\end{tabular}

G - genotype (MON - monomutant, NON - nonmutant)

$\mathrm{D}$ - diet (magnesium oxide - MgO supplementation)

Table 6

Least squares means for the effects of diet (D) and genotype (G) on meat quality traits of longissimus dorsi muscle (Einfluss des Futters (D) und des Genotyps (G) auf die Fleischqualität des m. longissimus dorsi)

\begin{tabular}{lccccccc}
\hline Item & \multicolumn{3}{c}{ Control } & \multicolumn{2}{c}{ MgO } & SE & Interaction \\
& & MON & NON & MON & NON & & G x D \\
\hline pH 45 min & LSM & $6.20^{\mathrm{a}}$ & $6.50^{\mathrm{b}}$ & $6.43^{\mathrm{b}}$ & $6.59^{\mathrm{b}}$ & 0.07 & - \\
Conductivity 24 h, $\mu \mathrm{S}$ & LSM & 5.93 & 4.52 & 4.77 & 4.95 & 0.49 & - \\
Lightness (L) 24 h & LSM & 48.19 & 49.00 & 48.83 & 47.38 & 1.28 & - \\
Drip loss 24 h, \% & LSM & $6.23^{\mathrm{a}}$ & $4.82^{\mathrm{bc}}$ & $5.02^{\mathrm{c}}$ & $4.13^{\mathrm{b}}$ & 0.28 & - \\
\hline
\end{tabular}

Within a row and comparison, means with different superscript letter differ $(\mathrm{P}<0.05)$

The LD of pigs fed diets supplemented with magnesium had lower percentage drip loss compared to pigs fed the control diet. No significant $(\mathrm{P}>0.05)$ differences were found in electrical conductivity and lightness between control and with magnesium supplemented pigs.

\section{Discussion}

The present study examined meat quality, fatty acids composition and the antioxidative stability in muscle of heterozygous (monomutant - MON) and normal MH (nonmutant - NON) of control and Mg supplemented pigs. Finding no significant differences among genotypes for total intramuscular fat and fatty acid composition is in agreement with results introduced earlier on British Landrace pigs by FLETCHER et al. (1988) and later on German Saddle Back pigs by NÜRNBERG et al. (1999). However, there was only a tendency to higher levels of intramuscular fat in pigs supplemented with magnesium. COFFEY and BRAZLE (1995) reported also an increased intramuscular fat and USDA quality grade after the inclusion of MM (Magnesium mica) in finishing diets for beef cattle but in pigs SCHAEFER et al. (1993) reported that intramuscular fat content and marbling score (APPLE et al., 2001) were not significantly affected by supplementing swine diets with Mg.

The accumulation of saturated fatty acid in pork is not desirable because of the negative effects on blood lipids (WOLFRAM, 2003). The higher linolenic acid concentration is positive for human nutrition. The increase of PUFA is connected with the higher intramuscular fat level in $\mathrm{Mg}$ supplemented pigs. Arachidonic acid and C20:5n-3 are precursors of eicosanoids. They are not affected by feeding. However, considering ratio n-6/n-3 fatty acids (Table 3) differences between control and $\mathrm{Mg}$ supplemented pigs were not significant. In pig, deposition of linoleic acid and linolenic acid is proportional to the level in the feed (ENSER et al., 1996, NÜRNBERG et al., 
2000). The elevating effect of $\mathrm{Mg}$ supplementation on n-3 fatty acid seems to be interesting from the nutritional point of view.

No differences in fatty acid composition between heterozygote and homozygote genotypes as well as between control and $\mathrm{Mg}$ supplemented pig were observed. Nevertheless, there was an increase in antioxidative capacity in muscle of $\mathrm{MgO}$ supplemented pigs compared to control pigs (Table 4). MgO seems to have a stabilizing effect on oxidation and this is possibly related to the development of meat quality (Table 6). Further explanation for Mg antioxidant properties was discussed by APPLE et al. (2001). They observed reduction of TBARS, albeit small, from supplementing swine diets with MM (Magnesium mica) and possibly an associciation with $\mathrm{Mg}$ ions replasing manganese ions in the activation of superoxide dismutase or in scavenging free radicals was introduced.

As was shown (NÜRNBERG et al., 1999) MHS (malignant hyperthermia susceptible) muscle obtained at 45 min had not only significant $(\mathrm{P}<0.05)$ lower $\mathrm{pH}$ but were more susceptible to peroxidation compared with MHR (malignant hyperthermia resistent) pigs. The effect of low $\mathrm{pH}$ has long been attributed to myoglobin denaturation and pale colour of PSE pork. Low $\mathrm{pH}$ has been shown to reduce the stability constant for the haemoglobin linkage and increase the autooxidation rate (RENERRE et al., 1992, TAM et al., 1998). They stated that the accumulation of metmyoglobin depends on several contradictory mechanisms, such as the rate of oxygen diffusion and consumption, pigment autoxidation and enzymatic reduction of metmyoglobin. Many different factors could ultimately affect the action of these mechanisms on fresh meat colour stability, breed and pre-slaughter handling. From this point of view studies on changing fatty acid composition in fresh and aged muscles of malignant hyperthermia pigs (with different $\mathrm{pH}$ decline and different water holding capacity) at defined feeding condition would be worth for further research.

Plasma magnesium concentrations were higher $(\mathrm{P}<0.05)$ in pigs fed the $\mathrm{MgO}$ supplemented diet then in pigs fed the control, comparable with results of D'SOUZA et al. (1999).

D'SOUZA et al. (1998) found higher $(\mathrm{P}<0.05)$ muscle $\mathrm{pH}$ at $40 \mathrm{~min}$ and $24 \mathrm{~h}$ after slaughter in pigs that were fed the MgAspartate supplemented diet. In contrast, other authors (KUHN et al., 1981, APPLE et al., 1999) did not find significant differences in muscle $\mathrm{pH}$ with $\mathrm{Mg}$ supplemented pigs. These discrepancies, possibly because of differences in animal testing (genotype, DNA test, biopsy) were discussed in different papers (LAHUCKY et al., 2004, BAHELKA et. al., 2004). Significant differences in drip loss $(\mathrm{P}<0.05)$ were found between heterozygotes control group and the other three groups which is in agreement with SCHAEFER et al. (1993), D'SOUZA et al. (1998, 1999), and HAMILTON et al. (2002). As was stated, pigs with a high content of fatty tissue are not guarantee for good meat quality and also n-3 fatty acid enriched diet fed to pigs did not affect the meat quality (NÜRNBERG et al., 1999) but as follows from our results the supplementation with $\mathrm{Mg}$ can reduce the percentage of drip loss and this appears to be beneficial in reducing exudative muscle of PSE pork.

\section{Conclusion}

Supplementation of pigs with MgO could not only improve the post mortem $\mathrm{pH}$ rate breakdown and water holding capacity but also improve antioxidant stability. The concentration of linolenic acid in muscles of pigs was increased by feeding MgO. 


\section{References}

APPLE, J. K.; DAVIS, J. R.; RAKES, L. K.; MAXWELL, CH. V.; STIVARIUS, M. R.; POHLMAN, F. W.: Effects of dietary magnesium and duration of refrigerated storage on the quality of vacuum-packaged, boneless pork loins. Meat Sci., 57 (2001), 43-53

APPLE, J. K.; MAXWELL, CH.; RODAS, B.; DAVIS, J.; RAKES, L.: Influence of Magnesium-Mica on Performance and Carcass Quality Traits of Growing-Finishing Swine. AAES Research Series 470 (1999), 23-28

BAHELKA, I.; LAHUCKY, R.; DEMO, P.; VASICEK, D.; KÜCHENMEISTER, U.; ENDER, K.: The effect of dietary magnesium oxide supplementation on carcass value and meat quality of pigs with different hyperthermia status. Czech J. Anim. Sci. (2004) (submitted).

BUEGE, J.A.; AUST, S.D.: Microsomal lipid peroxidation. Meth. Enzymol. (1978), 52 (1995), 302-310

COFFEY, K.P.; BRAZLE, F.K.:

Performance of finishing steers offered magnesium-mica in the feedlot Ration. Kansas State University, Southeast Agriculture Research Report., 733 (1995), 15-19

D’SOUZA, D. N.; WARNER, R. D.; LEURY, B. J.; DUNSHEA, F. R.:

The Effect of Dietary Magnesium Aspartate Supplementation on Pork Quality. J. Anim. Sci., 76 (1998) 104-109

D’SOUZA, D. N.; WARNER, R. D.; DUNSHEA, F. R.; LEURY, B. J.:

Comparison of different dietary magnesium supplements on pork quality. Meat Sci., 51 (1999), 221-225

ENSER, M.; WHITTINGTON, F. M.; WOOD, J. D.;COLE, D. J.; WISEMAN, J.:

Effect of dietary linoleic acid on the fatty acid composition of pig muscle. Anim. Prod., 51 (1990), 572 (Abstract)

ENSER, M.; HALLETT, K.; HEWITT, B.; FURSEY, A.J.; WOOD, J.D.:

Fatty Acid Content and Composition of English Beef, Lamb and Pork at Retail. Meat Sci., 42 (1996) 4, 443-456

FLETCHER, J.E.; ROSENBERG, H.; MICHAUX, K.; CHEAH, K.S.; CHEAH, A.M.:

Lipid analysis of skeletal muscle from pigs susceptible to malignant hyperthermia. Biochem. Cell Biol. 66 (1988), 917-921

FUJII, J.; OTSU, K.; ZORZATO, F.; DE LEON S.; KHANNA, V. K.; WEILER, J.; O’BRIEN, P.J.; MCLENNAN, D. H.:

Identification a mutation in porcine ryanodine receptor associated with malignant hyperthermia. Science (Washington DC), 253 (1991), 448-451

HAMILTON, D.N.; ELLIS, M.; HEMANN, M. D.; MCKEITH, F. K.; MILLER, K. D.; PURSER, K. W.: The impact of longissimus glycolytic potential and short-term feeding of magnesium sulfate heptahydrate prior to slaughter on carcass characteristics and pork quality. J. Anim. Sci., 80 (2002), 1

HONIKEL, K.O.: Reference methods for assessment of physical characteristics of meat. Meat Sci., 49 (1998) 4, 447-457

KIETZMANN, M.; JABLONSKI, M.:

Zur Stressabschirmung mit Mg-aspartat-Hydrochlorid auf Stressreaktion. Zbl. Vet. Med. 31 (1985), 321-333

KUHN, G.; NOWAK, A.; OTTO, E.; ALBRECHT, V.; GASSMANN, B.; SANDNER, E.; PRZYBILSKI, H.; ZAHN, L.:

Untersuchngen zur Beeiflussung der Fleischbeschaffenheit mit Hilfe spezieller Behandlungsverfahren beim Schwein. 1. Mitt.: Einfluss von Stress und präventiver Magnesiumzufütterung auf ausgewählte Parameter des Schlachtkörperwertes und des Blutserums. Arch. Tierz., Berlin 24 (1981), 217-225

LAHUCKY, R.; KRSKA, P.; KÜCHENMEISTER, U.; NÜRNBERG, K.; BAHELKA, I.; DEMO, P.; KUHN,

G.; ENDER, K.: Influence of dietary vitamin E supplementation on antioxidative status in muscle and meat quality of pigs. Czech J. Anim. Sci., 46 (2001) 7, 327-332

LAHUCKY, R.; KÜCHENMEISTER, U.; BAHELKA, I.; VASICEK, D.; LIPTAJ, T.; ENDER, K.: The Effect of Dietary Magnesium Oxide Supplementation on Post Mortem ${ }^{31} \mathrm{P}$ NMR Spectroscopy Parameters, Rate of $\mathrm{Ca}^{2+}$ Uptake and ATPase Activity of longissimus dorsi and Meat Quality of Heterozygous and Normal on Malignant Hyperthermia Pigs. Meat Sci. (2004) (in press).

LUDVIGSEN, J.B.: Intermediary magnesium- and calcium metabolism in stress-susceptible pigs. EAAP publication No. 55 (1985), 106-118

NÜRNBERG, K.; KÜCHENMEISTER, U.; ENDER, K.; NÜRNBERG, G.; HACKL, W.: Influence of dietary n-3 fatty acids on the membrane properties of skeletal muscle in pigs. Fett/Lipid, 100 (1998), 353-358

NÜRNBERG, K.; KUHN, G.; KÜCHENMEISTER, U.; ENDER, K.: 
Nutritional and genetic influences on meat and fat quality in pigs. Proc. Joint Session of the EAAP Commissions on Pig Production, Animal Genetics and Animal Nutrition 100 (2000), 73-79

OTTEN, W.; BERRER, A.; HARTMANN, S.; BERGERHOFF, T.; EICHINGER, H.M.:

Effects of magnesium fumarate supplementation on meat quality of pigs. In Proceedings $38^{\text {th }}$ international congress of meat science and technology (pp. 117-120), Clermont-Ferrand (1992), France

OWEN, V. J.; TASKE, N. L.; LAMB, G. D.:

Reduced $\mathrm{Mg}^{2+}$ inhibition of $\mathrm{Ca}^{2+}$ release in muscle fibers of pigs susceptible to malignant hyperthermia. Am. J. Physiol., 272 (1997), C203-C211

RAMSEY, C.B.; L.L. HAMMAN; MILLER, M.F.:

Vitamin/mineral nutritional modulation, stress, and hot-fat trimming effects on quality of pork from pigs monomutant for the PSE gene. J. Anim. Sci. 73 (Suppl. 1), (1995), 160 (Abstract)

RENERRE, M.; ANTON, M.; GATEELLIER, P.: Autoxidation of purified myoglobin from two bovine muscles. Meat Sci. 32 (1992), 331-342

SCHAEFER, A. L.; MURRAY, A. C.; TONG, A. K. W.; JONES, S. D. M.; AND A. P. SATHER:

The effect of ante mortem electrolyte therapy on animal physiology and meat quality in pigs segregating at the halothane gene. Can. J. Anim. Sci. 73 (1993), 231-239

TAM, L.G.; BERG, E.P.; GERRARD, D.E.; SHEISS, E.B.; TAN, F.J.; OKOS, M.R.; FORREST, J.C.:

Effect of Halothane Genotype on Porcine Meat Quality and Myoglobin Autoxidatin. Meat Sci. 49 (1998) 1, 41-53

WATSON, H.B.; MAXWELL, C.V.; de RODAS, B.Z.; APPLE, J.K.; COFFEY, K.P.; JOHNSON, Z.B.; POHLMAN, F.W.:

Effects of magnesium-mica on performance and carcass quality of growing-finishing swine. J. Anim. WOLFRAM, G.: Sci. 77 (Suppl. 1), (1999), 67 (Abstract)

Dietary fatty acids and coronary heart disease. Eur. J. Med. Res. (2003) 8, 321-324

Received: 2003-11-21

Accepted: 2004-02-27

Author's addresses

Dr. RUDOLF LAHUCKY*, IVAN BAHELKA, JOZEF MOJTO

Research Institute of Animal Production

Hlohovska 2

94991 Nitra

Slovak Republik

E-Mail: lahucky@vuzv.sk

Dr. KARIN NÜRNBERG, Dr. ULRICH KÜCHENMEISTER, Dr. GERD NÜRNBERG, Prof. Dr. Dr. h.c. KLAUS ENDER

Research Institute for Biology of Farm Animals Dummerstorf

Wilhelm-Stahl-Allee 2

D-18196 Dummerstorf

Germany

*Corresponding Author 